Research Article

\title{
New Records of Atypical Coral Reef Habitat in the Kimberley, Australia
}

\author{
Z. T. Richards, M. Bryce, and C. Bryce \\ Aquatic Zoology, West Australian Museum, Locked Bag 49, Welshpool DC, WA 6986, Australia \\ Correspondence should be addressed to Z. T. Richards; zoe.richards@museum.wa.gov.au
}

Received 17 January 2013; Accepted 13 March 2013

Academic Editor: Jakov Dulčić

Copyright (c) 2013 Z. T. Richards et al. This is an open access article distributed under the Creative Commons Attribution License, which permits unrestricted use, distribution, and reproduction in any medium, provided the original work is properly cited.

\begin{abstract}
New surveys of the Kimberley Nearshore Bioregion are beginning to fill knowledge gaps about the region's marine biodiversity and the national and international conservation significance of this little-known tropical reef system. Here we report the recent finding of two unique coral habitats documented at Adele Island and Long Reef during the Woodside 2009/2010 Collection Project surveys. Firstly, we report the finding of a subtidal zone of mixed corallith and rhodolith habitat which appears on current records, to be unprecedented in Australia. Secondly, we report the discovery of an atypical Organ Pipe Coral habitat zone and provide empirical evidence that this commercially valuable species reaches an unparalleled level of benthic cover. We provide additional details about the wider hard and soft coral assemblages associated with these unique habitats; discuss the potential biological causes and consequences of them, and make recommendations to benefit their conservation.
\end{abstract}

\section{Introduction}

Around the globe, most tropical reef locations have been the focus of at least some scientific studies. One of the last regions of shallow-water reef remaining to be explored is the Kimberley (north-west Australia). Renowned for huge tidal exchanges up to $11 \mathrm{~m}$, frequent cyclones and crocodiles, this region has experienced little reef-based research apart from a series of biodiversity surveys conducted by the Western Australian Museum in the 1990s. Despite the growing public and industrial interest in this frontier region, the diversity of the tropical Kimberley reefs remains largely unknown, even at the coarse habitat level.

Geomorphological surveys of reef development in Western Australia suggest that reefs in the Kimberley coastal bioregion are uniquely characterized by the development of Holocene accretionary veneers of coral-algal limestone ( $>12,000$ years old) on a Proterozoic basement $(2,500-543$ million years old) [1]. Neighbouring reefs on the northwest shelf (i.e., within the Western Pilbara and West Coast Bioregions) have origins in the Pleistocene (25 million12,000 years ago). Thus, contemporary reefs in the Kimberley appear to have more recent origins than others in Western Australia; however, the extent to which the difference in age translates to compositional differences between reefs remains to be resolved.

Along the Kimberley continental edge, there is extensive development of oceanic reefs. The offshore reefs (such as Ashmore, Cartier, and Scott Reefs) have been extensively surveyed as part of National and Regional management plans [2-9] and contain a surprising diversity of marine life given their isolation, including a high diversity of hard and soft corals. Despite forming a separate and distinct bioregion to the Oceanic Shoals [10, 11], only occasional coral collecting has been conducted within the nearshore Kimberley bioregion [12].

To address this information gap, a new project began in 2008 intended to quantify the diversity, distribution, and abundance of hard and soft corals along the Kimberley coast with that of other marine fauna and flora. The Woodside Collection Project (Kimberley): 2008-2011 (henceforth, the Woodside Project) (http://www.museum.wa.gov.au/kimberley/marine-life-kimberley-region) will combine inshore and offshore data to fill various important biogeographic and 
taxonomic knowledge gaps. This will help define the current knowledge concerning the region's biodiversity to aid conservation managers, industry, and government in establishing the national and international conservation significance of the region.

Here we describe two unusual benthic habitats discovered during the Woodside 4 Project surveys in 2009 at Adele Island and in 2010 at Long Reef. We will also discuss their potential biological causes, consequences, and significance and make recommendations to benefit their conservation.

\section{Methods}

2.1. Site Description. Adele Island $\left(15^{\circ} 31.3^{\prime} \mathrm{S}, 123^{\circ} 9.5 .0^{\prime} \mathrm{E}\right)$ is situated approximately $90 \mathrm{kms}$ from the coastline on the inner section of the north-west shelf. Approximately $17 \mathrm{~km}$ long and $9 \mathrm{~km}$ wide, Adele is a true reef platform with a vegetated centre. The reef is considered one of the largest and mature of the Sahul Shelf [13]. Wilson [14] describes the reef platform as, "a bioherm ... [whose] top is a cap of Quaternary reefal limestone, built on an inundated rocky hill of the dissected Kimberley Basis margin over a Proterozoic basement." Prevailing westerly wind, swell, and diurnal tides, with up to $11 \mathrm{~m}$ range on high-water springs, have shaped the intertidal reef platform (rampart) that is heavily etched with small drainage channels and low, widely spaced ridges running parallel to the reef edge that resemble a series of long low and wide corrugations. Beyond the rampart, the reef slopes into sublittoral fore-reef and back-reef zones featuring hard corals, soft corals, hydroids, bryozoans and macroalgae, such as Sargassum.

Long Reef $\left(15^{\circ} 56.5^{\prime} \mathrm{S}, 124^{\circ} 12.5^{\prime \prime} \mathrm{E}\right)$ is situated approximately $28 \mathrm{kms}$ from the coastline, also on the inner part of the NW Sahul Shelf. It is a north-south orientated elongated platform reef that is approximately $27 \mathrm{~km}$ long and $12 \mathrm{~km}$ wide, with a similar geological history to Adele Island. It was built on antecedent Proterozoic features that are remnants of topographic high points of the submerged Kimberley Basin margin [14]. Contemporary reef growth is controlled by wind, swell and extreme tidal exchanges. Long Reef features a large intertidal reef pavement zone resembling others in the inshore Kimberley such as Adele, but in contrast to Adele an island has not formed. There is, however, a central sandy spine running down the centre of the reef. The flat midlittoral reef pavement is covered with turf algae and tide pools which are fringed with small coral colonies. The reef pavement extends down to a narrow, honeycombed, and terraced fore-reef ramp that forms small drainage cascades resembling the low tide cascades of Montgomery Reef [15]. Subtidally, there is a steep fore-reef slope that descends beyond the $20 \mathrm{~m}$ contour and a fractured reef base with hard corals, sponges, hydroids, and other fauna and flora. The reef on the leeward side is gently sloping.

2.2. Field Surveys. Hard and soft coral biodiversity at Adele Island and Long Reef (Figure 1) were surveyed for the first time using standard benthic monitoring techniques. At Adele Island 13 stations were surveyed in October 2009

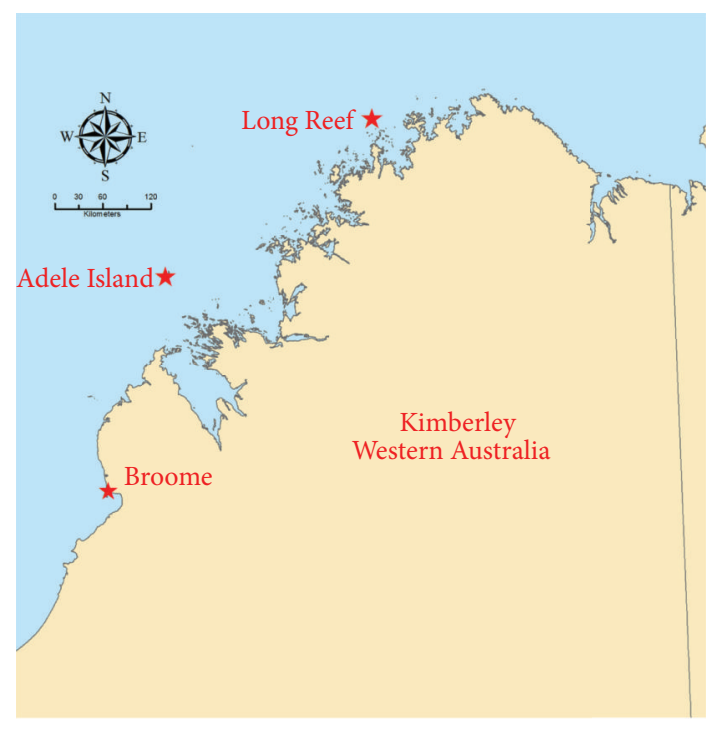

Figure 1: Map of the Kimberley coastline marking the location of Adele Island and Long Reef.

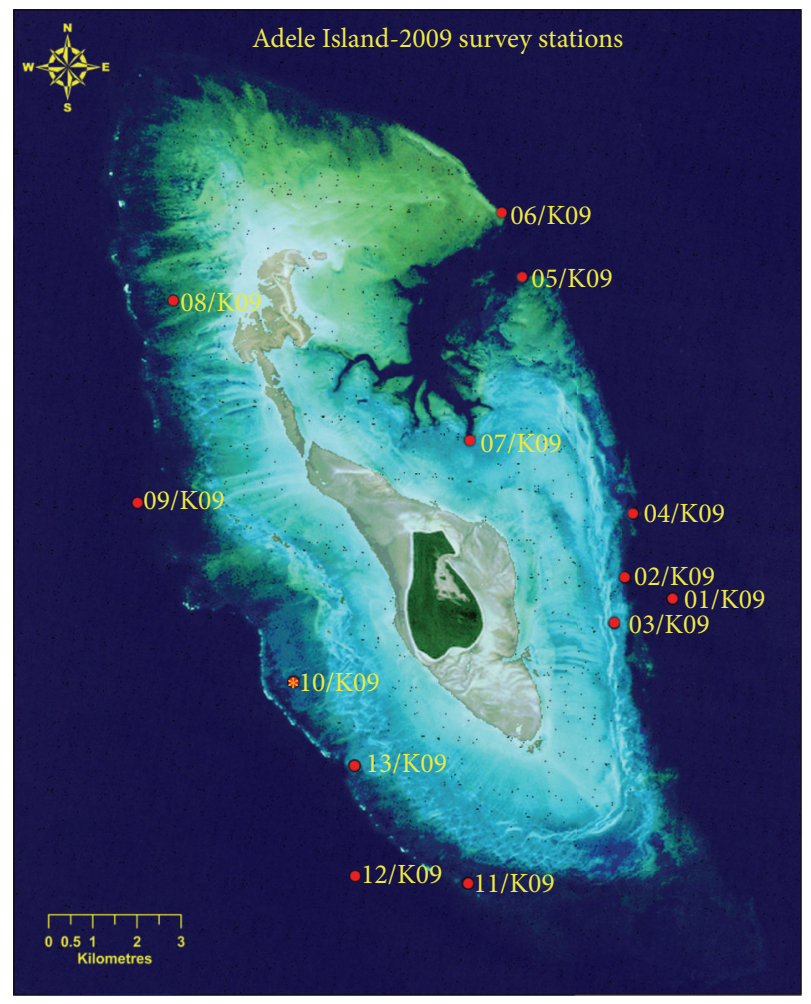

FIGURE 2: Satellite image of the extensive coral reef surrounding Adele Island with survey stations highlighted, the rollolith habitat zone is denoted by a star.

(Figure 2). Eleven stations were surveyed using SCUBA and two intertidal stations were surveyed. At Long Reef 15 stations were surveyed in October 2010 (Figure 3), nine stations using SCUBA and six stations were intertidal.

The mean species richness (+SE) of hard corals was calculated at each station from four replicated $15 \mathrm{~m} \times 1 \mathrm{~m}$ wide 


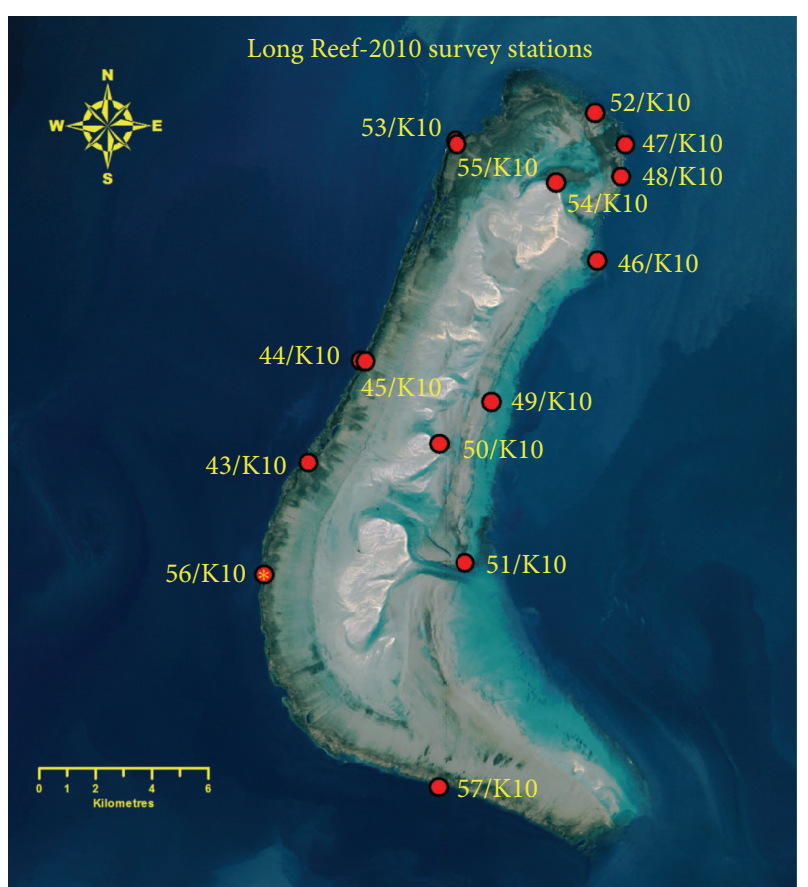

FIGURE 3: Satellite image of Long Reef with survey stations highlighted, the Tubipora habitat denoted by a star.

coral biodiversity belt transects. In addition, a 20-minute rapid visual search over the station (covering approximately $1000 \mathrm{~m}^{2}$ ) was conducted to detect rare and infrequent species. The total hard coral assemblage at each station was documented from pooled transect and rapid visual assessment records. For soft corals, a 60-minute rapid visual search was conducted over each station to obtain a thorough list of the soft coral assemblage.

In addition, during the spring low tide of the 24th October 2010, six $10 \mathrm{~m}$ long point intercept transects were conducted in the exposed fore-reef ramp to quantify the benthic coverage of Tubipora sp. Our intention here is to describe two unusual benthic habitats that were encountered on these expeditions in an ecological context and articulate the extent of surveying we have conducted at these inshore Kimberley locations in order to establish the prevalence and significance of the new habitats.

\section{Results}

3.1. Coralliths and Rhodoliths. Intertidal and subtidal surveys of Adele Island revealed extensive development of hard and soft coral communities. Seventy-eight species of scleractinian coral were recorded in intertidal and shallow water stations $(<6 \mathrm{~m}$ depth). The level of hard coral diversity increased to 176 species with additional surveying at subtidal sites $(>14 \mathrm{~m}$ depth). These records indicate that approximately half of all the hard coral species currently known to occur in the offshore and inshore Kimberley bioregions are present at Adele Island [16].
Octocoral biodiversity in intertidal and shallow water stations under $6 \mathrm{~m}$ depth was species poor, increasing considerably with greater depth. Only four species of octocoral were recorded in habitats under $6 \mathrm{~m}$ depth (Heliopora coerulea, Lobophytum sp., and Anthelia sp., Sansibia sp.), whereas 28 species were recorded at a depth of $6 \mathrm{~m}$ to $14 \mathrm{~m}$.

At station 10/K9, on the south west side of Adele Island a curious zone of benthic fauna was observed at the southern edge. This station was in $<4 \mathrm{~m}$ depth on the midlittoral back reef. It was a high energy, current swept consolidated reef platform with many depressions leading to a labyrinth of underplatform tunnels. The depressions contained course sand and coral rubble. Fifty-five species of hermatypic coral were recorded at this station with the five most commonly encountered species on transects being Goniastrea retiformis, Acropora papillare, Favites halicora, Goniastrea pectinata, and Porites annae. Within the Alcyonaria only the blue coral, Heliopora coerulea, and one species of Anthelia sp. were recorded.

At the southern edge of station $10 / \mathrm{K} 9$, the consolidated habitat gave way to a rubble bed. This was dominated by a mixed assemblage of coralliths (free-living live coral nodules) and rhodoliths (free-living balls of coralline algae) (herein called the rhollolith zone, sensu Baarli, 2010-where rollolith refers to motile balls of mixed origin, i.e., coral, algae, polychaete or bryozoan). Among the coralliths, four different species of coral were identified (Pavona venosa, Psammocora profundacella, Cyphastrea chalcidicum, and Millepora sp.) (Figures 4(a), 4(b), and 4(d)). Milleporinid coralliths were the most abundant and between 3 and 5 coralliths of the other genera were observed within the section of the rollolith zone that was examined. The maximum size of the coralliths was $12 \mathrm{~cm}$ (greater diameter).

Rhodoliths (Figure 4(c)) dominated the assemblage in the rollolith zone and covered the substrate. The largest rhodolith recorded was $8 \mathrm{~cm}$ (greater diameter). Generally the rhodoliths formed as a cluster of short $(>1 \mathrm{~cm})$ dense branches, some of which appeared to be formed around coral rubble or shells, others appeared to be entirely of algal origin.

3.2. Long Reef: Tubipora. Intertidal and subtidal surveys at Long Reef revealed extensive development of hard coral and soft coral communities. Preliminary systematic studies indicate 200 species of scleractinian corals occur at Long Reef, 68 of which occur in the intertidal zone. Octocoral biodiversity followed the same trend as Adele Island with low biodiversity in intertidal and shallow water stations under $6 \mathrm{~m}$ depth, and increasing to 29 species between $6 \mathrm{~m}$ and $14 \mathrm{~m}$.

During a spring low tide surveys of Long Reef we encountered an atypical habitat zone dominated by the Organ Pipe Coral, Tubipora sp. on the reef platform bordering station 56/K10 (Figures 5(a) and 5(b)). The platform was on the south west side of Long Reef and featured many tide pools and a covering of algal turf. The platform extended down to a narrow, honeycombed fore-reef ramp that was terraced forming small drainage waterfalls. Numerous blowholes occurred along the edge of the reef; however, these were only evident for a short duration over the lowest point of the tide. 


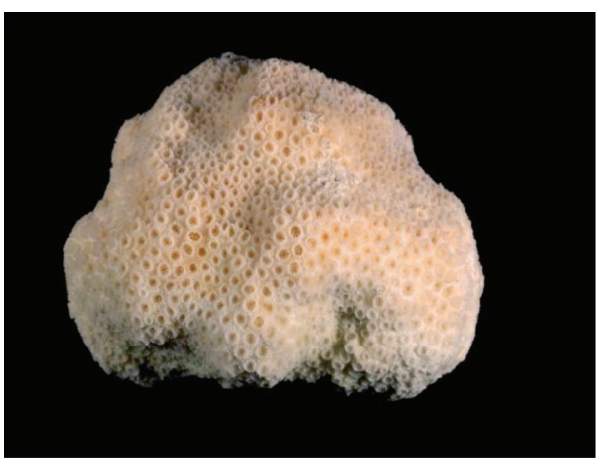

(a)

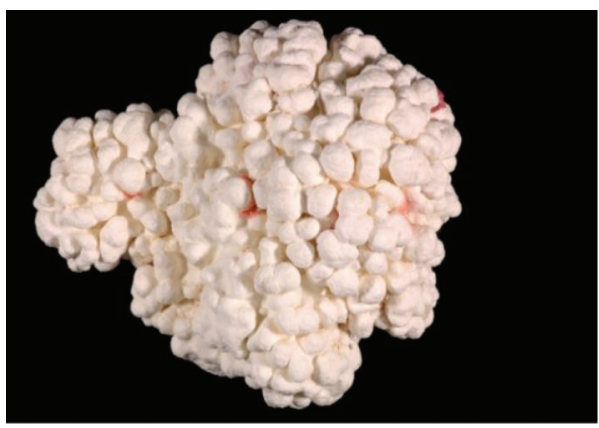

(c)

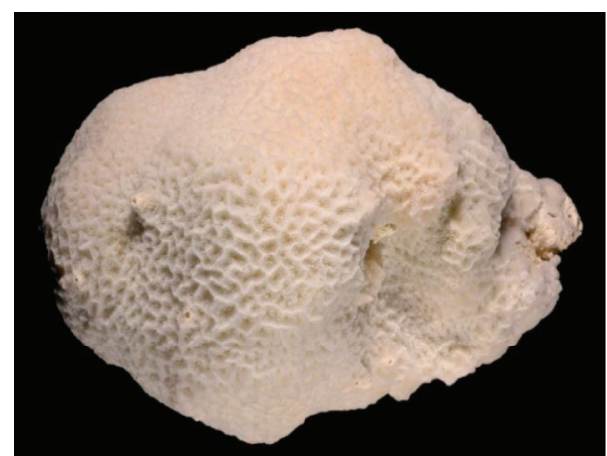

(b)

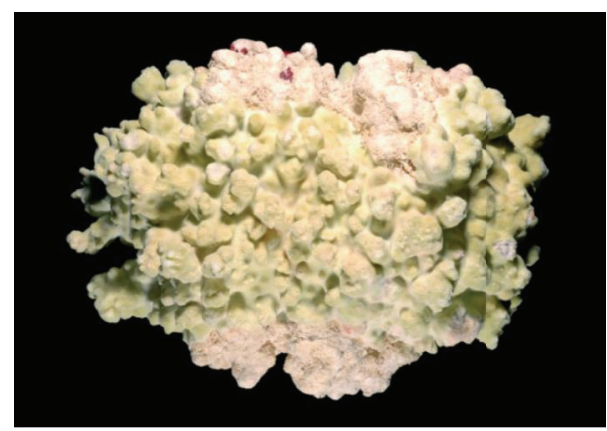

(d)

Figure 4: Rolloliths collected from Adele Island. (a) Cyphastrea chalcidicum corallith. (b) Pavona venosa corallith. (c) Red coralline algae rhodolith. (d) Milleporina corallith. Skeletal photos Roger Springthorpe Australian Museum.

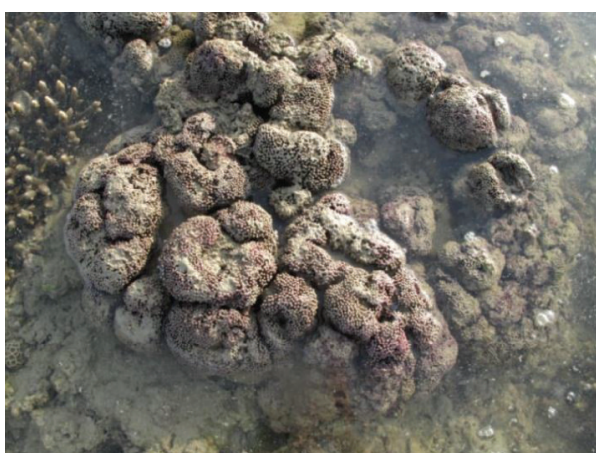

(a)

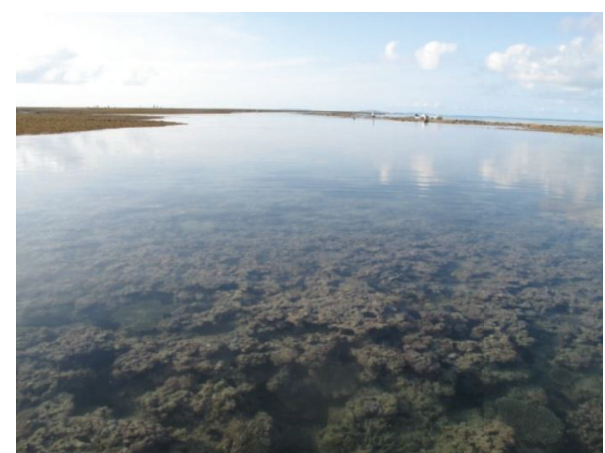

(b)

Figure 5: Organ Pipe Coral at Long Reef. (a) A single colony of Organ Pipe Coral (Tubipora sp.). (b) The narrow fore-reef habitat on the western side of Long Reef showing the prolific development of Tubipora as the tide advances.

Point-intercept transects conducted to quantify the percent cover of Tubipora in the zone verified that Tubipora was the dominant benthic organism with a mean of $27.67 \%$ ( $\pm 3.24 \mathrm{SE})$ cover. Turf algae $(22 \% \pm 5.49 \mathrm{SE})$; sand/rubble $(18 \% \pm 4.26 \mathrm{SE})$; and coralline algae $(9 \% \pm 2.5 \mathrm{SE})$ inhabited the majority of the remaining space. Ten other genera of scleractinian coral were recorded on benthic cover transects within this habitat (Platygyra, Acropora, Goniastrea, Favia, Favites, Galaxea, Symphyllia, Goniopora, Seriatopora, and Porites); however, their combined coverage was $<20 \%$. Six additional species of octocorallia were recorded within this Tubipora habitat zone (Heliopora coerulea, Lobophytum sp.,
Cladiella sp., Capnella sp., Xenia sp., and Briareum sp.), as well as a small number of sponges and hydroids.

\section{Discussion}

4.1. Rolloliths. Free-living spheroidal corals (i.e., coralliths) were first noted from shallow tropical reef environments in Vanuatu and Indonesia in the late 1800s [17], and palaeontological studies have dated coralliths back to the Eocene (approx. 65 mya, [18]). Throughout the 70s, numerous papers arose concerning coralliths, conferring they occur right across the globe from Bermuda to Madagasgar [19, 20]. More 
recently, assemblages of coralliths have been recorded in the Cook Islands [21]; Barbados [22]; the North West Indian Ocean [23]; Galapagos [24]; Mexico; and the Red Sea [25]. In Australian waters, there are currently only isolated records of coralliths. For example, Porites lutea has been observed to form motile balls on the depositional reef flats at Heron Island [26] and Cyphastrea microphthalma forms motile balls at the Cocos Islands [27].

The largest corallith encountered at Adele Island was a colony of Pavona venosa which was $12 \mathrm{~cm}$ (greatest diameter). This is small in comparison to the normal size of this species which has the potential to grow to at least $1 \mathrm{~m}$ (greatest diameter) when attached to the substrate. Coralliths are likely to be size restricted because if they grow too large they would become partially or completely buried. It is also worthwhile noting that no attached forms of the four corallith species were recorded at station 10/K9; however, these four coral species were encountered in low abundance at other Adele Island stations.

Rhodolith beds, however, are very widespread. They are distributed from the poles to the tropics and can accumulate to form extensive communities on a wide variety of sediments in both deep and shallow water [28, 29]. The largest beds reported are on the Brazilian Shelf spanning 23 degrees of latitude $[28,30,31]$. In Brazil, rhodoliths are so abundant they are commercially mined [32]. Numerous studies have reported that rhodolith beds are important ecologically because they support a high diversity of associated flora and infauna [28, 33-35].

In Australia, rhodolith beds are also relatively widespread, occurring off Western Australia [36] in cold-temperate waters of southern Australia [37] and in southern Queensland where they cover up to $50 \%$ of the sea-floor from 50 to $110 \mathrm{~m}$ depth [38]. A study conducted at Montgomery Reef in the Kimberley describes rhodoliths as being important contemporary reef builders [15]. Rhodoliths are reportedly so abundant at Montgomery Reef that they form containment banks which impound a raised lagoonal habitat, the water from which feeds the unique system of low-tide cascades. Some of the Montgomery Reef rhodoliths have a core of coral fragment, but many are constructed entirely of algae. Similarly, on South Turtle Reef in Talbot Bay (inshore Kimberley), rhodolith banks form along the reef crest and enclose small pools that retain water over the low tide [39].

While there are records of rhodoliths from the Kimberley, there are, however, no current records of coralliths (at Montgomery Reef, Talbot Bay, or any other Kimberley locations). Moreover, there are no current records of Australian coral reef habitat featuring a mixed assemblage of living coralliths (from a variety of genera) and rhodoliths. Thus, the Adele Island fore-reef rollolith zone appears to be relatively rare. Therefore, our findings provide the first record of mixed corallith and rhodolith habitat for the Kimberley coastal bioregion and also for Australia.

Further taxonomic study is needed to confirm which species of algae form the rhodolith community at Adèle Island. Nongeniculate coralline algae are considered to be challenging to identify, and at least eight genera belonging to three families of Corallinales (Hapalidiaceae, Corallinaceae, and Sporolithaceae) contain species that commonly form rhodoliths. The rhololith bed off Western Port, Victoria, for example, is composed of four species (Hydrolithon rupestre (Foslie) Penrose, Lithothamnion superpositum Foslie, Mesophyllum engelhartii (Foslie) Adey, and Neogoniolithon brassica-florida (Harvey) Setchell and Mason) [37] so it is likely that the Kimberley rhodolith beds also contains multiple species.

The rolloliths of Adele Island most likely form in the lee of prevailing wave action, as a cumulative response to unidirectional currents and the tidal pull on surface sediments. This maintains periodic yet constant movement enabling persistent growth on all sides of the colony [21]. The frequent disturbance of bottom sediments by browsing fishes and gastropods (bioturbation) has also been hypothesized to contribute towards the unique spherical form [19, 40, 41]. Holothurians and sea urchins have also been observed to aid in keeping coralliths and rhodoliths in motion [25].

4.2. Tubipora. Tubipora sp. is the only known hard, calcitic, reef-building alcyonarian (soft) coral. Its skeleton consists of calcite spicules fused into upright, parallel tubes connected by transverse platforms hence its common name of Organ Pipe Coral. Organ Pipe Coral is normally sporadic to rare throughout its range which spans the Indo-Pacific from the Red Sea and East Africa to Southeast Asia, Micronesia, Australia, and the Pacific [42]. Tubipora has, however, been observed in large quantities near Rat Island off Gladstone in Queensland, Australia (Philip Alderslade pers. comm.), and at an undisclosed location in Papua New Guinea [43]. The highest published benthic coverage estimate of Tubipora sp. is $11.9 \%$ from one location in the Red Sea [44]. Our quantitative data showing $27.67 \%$ (+3.24 SE) coverage of Tubipora at this one Long Reef location suggests this is an exceptionally rare, high density population.

Tubipora was once thought to be a single ubiquitous species: Tubipora musica Linnaeus 1758 (Family Tubiporidae, Order Stolonifera, Class Anthozoa, Phylum Cnidaria) however there are now several nominal species of Tubipora. Our preliminary systematic study has raised doubt about which species of Tubipora is present in the Kimberley. Hence, further investigations, based on gross morphology of its skeleton and molecular sequencing, are necessary to confirm or refute prior assumptions about the species identity. In addition to the required taxonomic research, further biological research is needed to understand the age, growth rate, reproductive biology, and molecular ecology of the Long Reef Tubipora in order to understand why they are so prevalent at this particular location.

Shared among the various nominal species of Tubipora is the distinctive bright red colour of the skeleton. The red colouration is a result of organic pigments, including carotenoids, which give the orange colour to carrots and the red colour to cooked lobsters. Carotenoids occur naturally in plants but are not manufactured by animals, so it is likely the Organ Pipe Coral assimilates the pigments via heterotrophic feeding on phytoplankton. Incorporating pigment into the skeleton is likely to serve the coral in two ways: firstly, it would assist light absorption and maximize the potential for 
photosynthesis by symbiotic dinoflagellates; and secondly, carotenoids may help protect chlorophyll from photo damage [45].

4.3. Conservation Implications. Both hard coral and calcified macroalgae are vital components of nearshore ecosystems in tropical and temperate systems through their contributions to carbon cycling and productivity [46]; the provision of habitats and their associated biodiversity; their role as nursery areas [47, 48]; and their contribution to the development of reef structures [49]. Rhodoliths also offer the potential to serve as paleoclimate proxies [40, 50-52]. A recent study measuring carbonate deposition in two slow-growing rhodolith species $\left(<200 \mu \mathrm{m} \mathrm{y}^{-1}\right)$ permitted biweekly sampling resolution leading the authors to suggest rhodoliths are unique, globally distributed palaeothermometers, which may help refine regional climate histories during the Holocene [53].

The remote location and lack of conservation management of Adele Island and Long Reef combined with the high density of rhodoliths/coralliths and Organ Pipe Coral in the unusual habitat zones we describe here renders these marine resources highly susceptible to harvesting pressure in the future. Traditional fishers have utilized the marine resources of the Kimberley region since the early eighteenth century $[54,55]$, but there is currently no historical record of hard corals, soft corals, or calcifying macroalgae being targeted. There is, however, substantial and rapidly growing trade in corals [56] including Organ Pipe Coral, which is used in the curio, jewellery, and aquarium industries because of its attractive bright red skeleton [57]. In consideration of this, Organ Pipe Coral is currently listed as Near-Threatened on the IUCN red-list of threatened species [57].

Scleractinian and nonscleractinian corals are afforded some amount of protection from international trade as they are listed under Appendix I and II of CITES; however, calcifying macroalgae are not listed. At an international level, we advocate the inclusion of rhodoliths under CITES regulation and that special conditions be made to ensure the trade of coralliths is monitored. Further, more timely access to national-level CITES trade data is needed to monitor trends in the export of marine resources.

It is important that regional marine resource managers direct special attention towards these atypical Kimberley habitats because corals and calcifying macroalgae are vulnerable to changes in the environment. Specific recommendations for conserving these unique benthic habitats include the establishment of marine protected areas in the Kimberley encompassing Adele Island and Long Reef and the inclusion of these locations in the existing program of Customs surveillance. Further research into Tubipora and rhodolith taxonomy is also important to support conservation efforts. Ongoing adaptive management and long-term monitoring of wild coral harvest in Western Australia are needed to manage risks and to ensure Western Australia's unique natural resources are protected. The Kimberley is the new frontier for tropical reef research and given the industrial interest in the region, more information is needed to provide the basis for sound decision-making and sustainable resource management.

\section{Acknowledgments}

This research was conducted as part of the Woodside Collection (Kimberley) project. The project is a Western Australian Museum initiative and sponsored by Woodside Energy. Project partner organisations are the Australian Museum, Queensland Museum, Museum and Art Gallery of the Northern Territory, Museum Victoria, and the Herbarium of Western Australia (DEC). The second author was funded as part of the Australian node of the Census of Marine Life (CReefs Program) studying the biodiversity of Australian biota, funded by the Australian Government under auspices of the Australian Institute of Marine Science, the Great Barrier Reef Research Foundation, and BHP Billiton. This research is part of Australian Biological Resources Study (ABRS) National Taxonomic Research Grant (no. 209-05) Taxonomy of tropical Australian Octocorallia (Anthozoa: Coelenterata) primarily from the Census of Marine Life “CReefs" expeditions (J. N. A. Hooper \& P. N. A. Alderslade). The authors are thankful for the help received by the project scientific staff and ship's company during survey voyages aboard the Kimberley Quest II. Special thanks to Dr. Barry Wilson for his useful discussions. Thanks also to Alison Sampey for the compilation of Figures 1-3.

\section{References}

[1] B. Brooke, "Geomorphology," in Marine Biological Survey of the Southern Kimberley, Western Australia, F. E. Wells, J. R. Hanley, and D. I. Walker, Eds., pp. 21-51, Western Australian Museum, Perth, Australia, 1995.

[2] J. K. Griffith, "The corals collected during September/October 1997 at Ashmore Reef, Timor Sea," A Report to Parks Australia, Western Australian Museum, Perth, Australia, 1997.

[3] M. Kospartov, M. Beger, D. Ceccarelli, and Z. Richards, An Assessment of the Distribution and Abundance of Sea Cucumbers, Trochus, Giant Clams, Coral, Fish and Invasive Marine Species at Ashmore Reef National Nature Reserve and Cartier Island Marine Reserve: 2005, UniQuest Pty Limited, DEWHA, 2006.

[4] D. Cecarelli, M. Kospartov, M. Beger, Z. Richards, and C. Birrell, An Assessment of the Impacts of Illegal Fishing on Invertebrate Stocks at Ashmore Reef National Nature Reserve, 2006, C \& R Consulting, DEWHA, 2007.

[5] P. F. Berry, Ed., Faunal Surveys of the Rowley Shoals, Scott Reef, and Seringapatam Reef, North-Western Australia, vol. 25 of Records of the Western Australian Museum Supplement, Western Australian Museum, Perth, Australia, 1986.

[6] P. F. Berry, Ed., Marine Faunal Surveys of Ashmore Reef and Cartier Island, North-Western Australia, vol. 44 of Records of the Western Australian Museum Series, Western Australian Museum, Perth, Australia, 1993.

[7] C. Bryce, Marine Biodiversity Survey of Mermaid Reef (Rowley Shoals), Scott and Seringapatam Reef, vol. 77 of Records of the Western Australian Museum Supplement, Western Australian Museum, Perth, Australia, 2009.

[8] K. Fabricius, "A brief photo guide to the shallow-water octocorals of the Rowley Shoals, Western Australia," Report, 
Department of Environment and Conservation, Government of Western Australia, 2008.

[9] Z. Richards, M. Beger, J. P. Hobbs, T. Bowling, K. Chongseng, and M. Pratchett, "Ashmore Reef National Nature Reserve and Cartier Island Marine Reserve Marine Survey 2009," ARC Centre of Excellence for Coral Reef Studies, Department of the Environment, Water, Heritage and the Arts, 2009.

[10] R. Thackway and I. D. Cresswell, Interim Marine and Coastal Regionalisation for Australia: An Ecosystem-Based Classification for Marine and Coastal Environments, Environment Australia, Canberra, Australia, 1998.

[11] M. Wood and D. Mills, A Turning of the Tide: Science for Decisions in the Kimberley-Browse Marine Region, A Western Australian Marine Science Institution (WAMSI), Perth, Australia, 2008.

[12] J. E. N. Veron and L. M. Marsh, Hermatypic Corals of Western Australia: Records and Annotated Species List, vol. 29 of Records of the Western Australian Museum, Western Australian Museum, Perth, Australia, 1988.

[13] C. Teichert and R. W. Fairbridge, "Some coral reefs of the Sahul Shelf," Geographical Review, vol. 28, no. 2, pp. 222-249, 1948.

[14] B. R. Wilson, The Biogeography of the Australian North West Shelf, Elsevier, New York, NY, USA, 2013.

[15] B. Wilson and S. Blake, "Notes on the origins and biogeomorphology of Montgomery Reef, Kimberley, Western Australia," Journal of the Royal Society of Western Australia, vol. 94, pp. 107119, 2011.

[16] Z. T. Richards, A. Sampey, and L. Marsh, "Synthesis of historic marine species data for the Kimberley, Western Australia (1880s-2009): hard corals," Records of the Western Australian Museum. In press.

[17] M. Weber, Introduction et description de l'Expedition, Mongraph no. 1, Siboga-Expeditie, 1902.

[18] P. D. Taylor and D. N. Lewis, Fossil Invertebrates, Natural History Museum, London, UK, 2005.

[19] P. W. Glynn, "Rolling stones amongst the scleractinia: mobile coralliths in the Gulf of Panama," in Proceedings of the 2nd International Coral Reef Symposium, vol. 2, pp. 183-198, 1974.

[20] M. Pichon, "Free-living scleractinian coral communities in the coral reefs of Madagascar," in Proceedings of the 2nd International Coral Reef Symposium, vol. 2, pp. 173-181, 1974.

[21] T. P. Scoffin, D. R. Stoddart, A. W. Tudhope, and C. Woodroffe, "Rhodoliths and coralliths of Muri Lagoon, Rarotonga, Cook Islands," Coral Reefs, vol. 4, no. 2, pp. 71-80, 1985.

[22] J. B. Lewis, "Spherical growth in the Caribbean coral Siderastrea radians (Pallas) and its survival in disturbed habitats," Coral Reefs, vol. 7, no. 4, pp. 161-167, 1989.

[23] M. R. Claereboudt, "Porites decasepta: a new species of scleractinian coral (Scleractinia, Poritidae) from Oman," Zootaxa, no. 1188 , pp. 55-62, 2006.

[24] P. W. Glynn and G. M. Wellington, Corals and Coral Reefs of the Galapagos Islands, University of California Press, Berkeley, Calif, USA, 1983.

[25] H. Reyes-Bonilla, R. Riosmena-Rodriguez, and M. S. Foster, "Hermatypic corals associated with rhodolith beds in the Gulf of California, México," Pacific Science, vol. 51, no. 3, pp. 328-337, 1997.

[26] G. Roff, "Corals on the move: morphological and reproductive strategies of reef flat coralliths," Coral Reefs, vol. 27, no. 2, pp. 343-344, 2008.
[27] J. E. N. Veron, Re-Examination of the Reef Corals of Cocos (Keeling), vol. 14, Records of the Western Australian Museum, Western Australian Museum, Perth, Australia edition, 1990.

[28] M. S. Foster, "Rhodoliths: between rocks and soft places," Journal of Phycology, vol. 37, no. 5, pp. 659-667, 2001.

[29] B. Konar, R. Riosmena-Rodriguez, and K. Iken, "Rhodolith bed: a newly discovered habitat in the North Pacific Ocean," Botanica Marina, vol. 49, no. 4, pp. 355-359, 2006.

[30] M. Kempf, "Notes of the benthic bionomy of the N-NE Brazilian shelf," Marine Biology, vol. 5, no. 3, pp. 213-224, 1970.

[31] G. M. Amado-Filho, G. Maneveldt, R. C. C. Manso, B. V. Marins-Rosa, M. R. Pacheco, and S. M. P. B. Guimarães, "Structure of rhodolith beds from 4 to 55 meters deep along the southern coast of Espírito Santo State, Brazil," Ciencias Marinas, vol. 33, no. 4, pp. 399-410, 2007.

[32] G. B. Baarli, M. Cachao, C. M. da Silva, M. E. Johnson, J. Ledesma-Vazquez, and A. M. E. Santos, "Fossil nodules of free living biota from the upper Pleistocene Mulegé formation, Playa La Palmita, Baja California Sur, Mexico," Publicaciones del Seminario de Paleontología de Zaragoza, vol. 9, pp. 75-78, 2010.

[33] C. Barbera, C. Bordehore, J. A. Borg, M. Glémarec et al., "Conservation and management of northeast Atlantic and Mediterranean maerl beds," Aquatic Conservation: Marine and Freshwater Ecosystems, vol. 13, no. 1, pp. S65-S76, 2003.

[34] G. Hinojosa-Arango and R. Riosèmena-Rodríguez, "Influence of rhodolith-forming species and growth-form on associated fauna of rhodolith beds in the Central-West gulf of California, México," Marine Ecology, vol. 25, no. 2, pp. 109-127, 2004.

[35] J. Hall-Spencer, J. Kelly, and C. A. Maggs, Assessment of Maerl Beds in the OSPAR Area and the Development of a Monitoring Program, Department of Environment, Heritage and Local Government, Dublin, Ireland, 2008.

[36] N. Goldberg, "Age estimates and description of rhodoliths from Esperance Bay, Western Australia," Journal of the Marine Biological Association of the United Kingdom, vol. 86, no. 6, pp. 1291-1296, 2006.

[37] A. S. Harvey and F. L. Bird, "Community structure of a rhodolith bed from cold-temperate waters (Southern Australia)," Australian Journal of Botany, vol. 56, no. 5, pp. 437-450, 2008.

[38] M. Lund, P. J. Davies, and J. C. Braga, "Coralline algal nodules off Fraser Island, Eastern Australia," Facies, no. 42, pp. 25-34, 2000.

[39] B. Wilson, S. Blake, D. Ryan, and J. Hacker, "Reconnaissance of species-rich coral reefs in a muddy, macro-tidal enclosed embayment - Talbot Bay, Kimberley, Western Australia," Journal of the Royal Society of Western Australia, vol. 94, pp. 251-165, 2011.

[40] M. S. Foster, R. Riosmena-Rodríguez, D. L. Steller, and W. J. Woelkerling, "Living rhodolith beds in the Gulf of California and their implications for paleoenvironmental interpretation," Geological Society of America Bulletin, vol. 318, pp. 127-139, 1997.

[41] E. C. Marrack, "The relationship between water motion and living rhodolith beds in the Southwestern Gulf of California, Mexico," Palaios, vol. 14, no. 2, pp. 159-171, 1999.

[42] K. Fabricius and P. Alderslade, Soft Corals and Sea Fans-A Comprehensive Guide to the Tropical Shallow Water Genera of the Central-West Pacific, the Indian Ocean and the Red Sea, Australian Institute of Marine Science, Townsville, Australia, 2001.

[43] J. E. N. Veron, Corals of the World, vol. 1-3, Australian Institute of Marine Science, 2000. 
[44] Y. Benayahu and Y. Loya, "Space partitioning by stony corals soft corals and benthic algae on the coral reefs of the Northern Gulf of Eilat (Red Sea)," Helgoländer Wissenschaftliche Meeresuntersuchungen, vol. 30, no. 1-4, pp. 362-382, 1977.

[45] J. Cvejic, S. Tambutte, S. Lotto, M. Mikov, I. Slacanin, and D. Allemand, "Determination of canthaxanthin in the red coral (Corallium rubrum) from Marseille by HPLC combined with UV and MS detection," Marine Biology, vol. 152, no. 4, pp. 855862, 2007.

[46] S. Hetzinger, J. Halfar, B. Riegl, and L. Godinez-Orta, "Sedimentology and acoustic mapping of modern rhodolith facies on a non-tropical carbonate shelf (Gulf of California, Mexico)," Journal of Sedimentary Research, vol. 76, no. 3-4, pp. 670-682, 2006.

[47] N. A. Kamenos, P. G. Moore, and J. M. Hall-Spencer, "Smallscale distribution of juvenile gadoids in shallow inshore waters; what role does maerl play?" ICES Journal of Marine Science, vol. 61, no. 3, pp. 422-429, 2004.

[48] N. A. Kamenos, P. G. Moore, and J. M. Hall-Spencer, "Nurseryarea function of maerl grounds for juvenile queen scallops Aequipecten opercularis and other invertebrates," Marine Ecology Progress Series, vol. 274, pp. 183-189, 2004.

[49] W. A. Nelson, "Calcified macroalgae critical to coastal ecosystems and vulnerable to change: a review," Marine and Freshwater Research, vol. 60, no. 8, pp. 787-801, 2009.

[50] A. Freiwald, R. Henrich, P. Schäfer, and H. Willkomm, "The significance of high-boreal to subarctic maerl deposits in northern Norway to reconstruct holocene climatic changes and sea level oscillations," Facies, vol. 25, no. 1, pp. 315-339, 1991.

[51] C. E. Cintra-Buenrostro, M. S. Foster, and K. H. Meldahl, "Response of nearshore marine assemblages to global change: a comparison of molluscan assemblages in Pleistocene and modern rhodolith beds in the Southwestern Gulf of California, México," Palaeogeography, Palaeoclimatology, Palaeoecology, vol. 183, no. 3-4, pp. 299-320, 2002.

[52] R. Nalin, C. S. Nelson, D. Basso, and F. Massari, "Rhodolithbearing limestones as transgressive marker beds: fossil and modern examples from North Island, New Zealand," Sedimentology, vol. 55, no. 2, pp. 249-274, 2008.

[53] N. A. Kamenos, M. Cusack, and P. G. Moore, "Coralline algae are global palaeothermometers with bi-weekly resolution," Geochimica et Cosmochimica Acta, vol. 72, no. 3, pp. 771-779, 2008.

[54] S. Fox, "Reefs and shoals in Australia-Indonesian relations: traditional Indonesian fisherman," in Australian in Asia: Episodes, A. C. Milner and M. Quilty, Eds., Oxford University Press, Melbourne, Australia, 1988.

[55] N. Stacey, Boats to burn: bajo fishing in the Australian fishing zone [Ph.D. thesis], Northern Territory University, Commonwealth of Australia, 2002, Ashmore Reef National Nature Reserve and Cartier Island Marine Reserve Management Plans, Environment Australia, Canberra, Australia, 1999.

[56] A. Rhyne, R. Rotjan, A. Bruckner, and M. Tlusty, "Crawling to collapse: ecologically unsound ornamental invertebrate fisheries," PLoS ONE, vol. 4, no. 12, Article ID e8413, 2009.

[57] D. Obura, D. Fenner, B. Hoeksema, L. Devantier, and C. Sheppard, "Tubipora musica," in IUCN, 2012. IUCN Red List of Threatened Species: Version 2012. 2, 2008, http://www.iucnredlist.org/. 

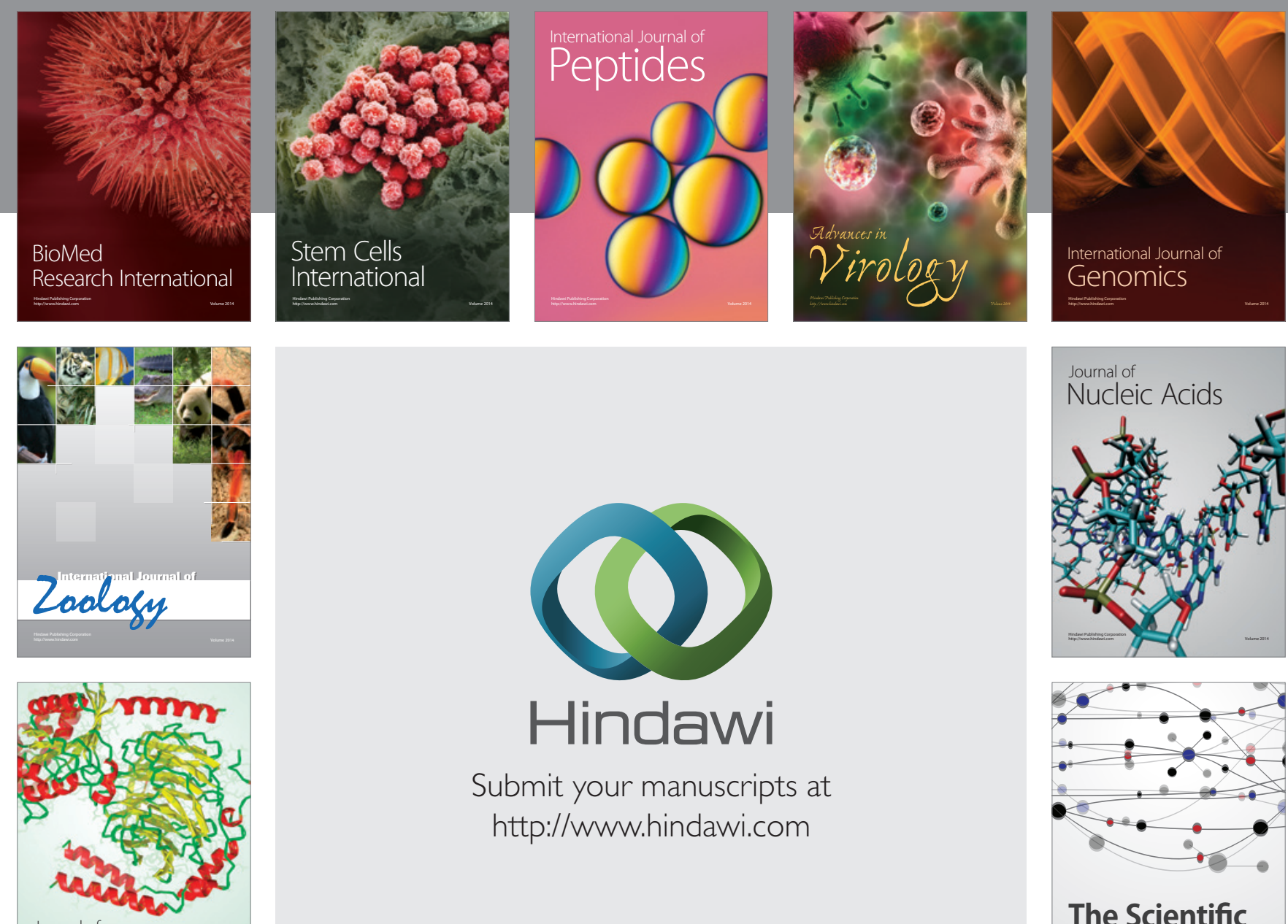

Submit your manuscripts at

http://www.hindawi.com

Journal of
Signal Transduction
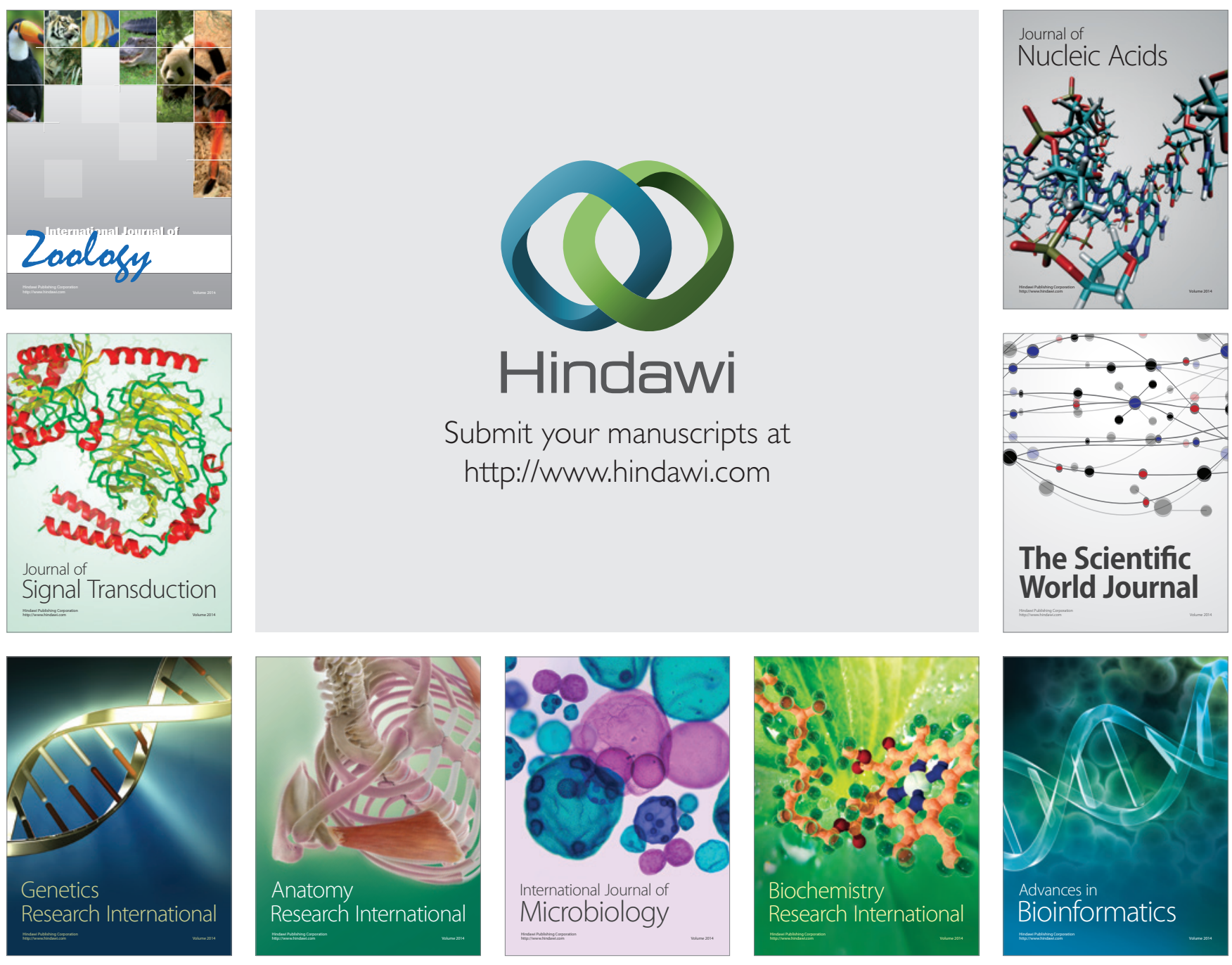

The Scientific World Journal
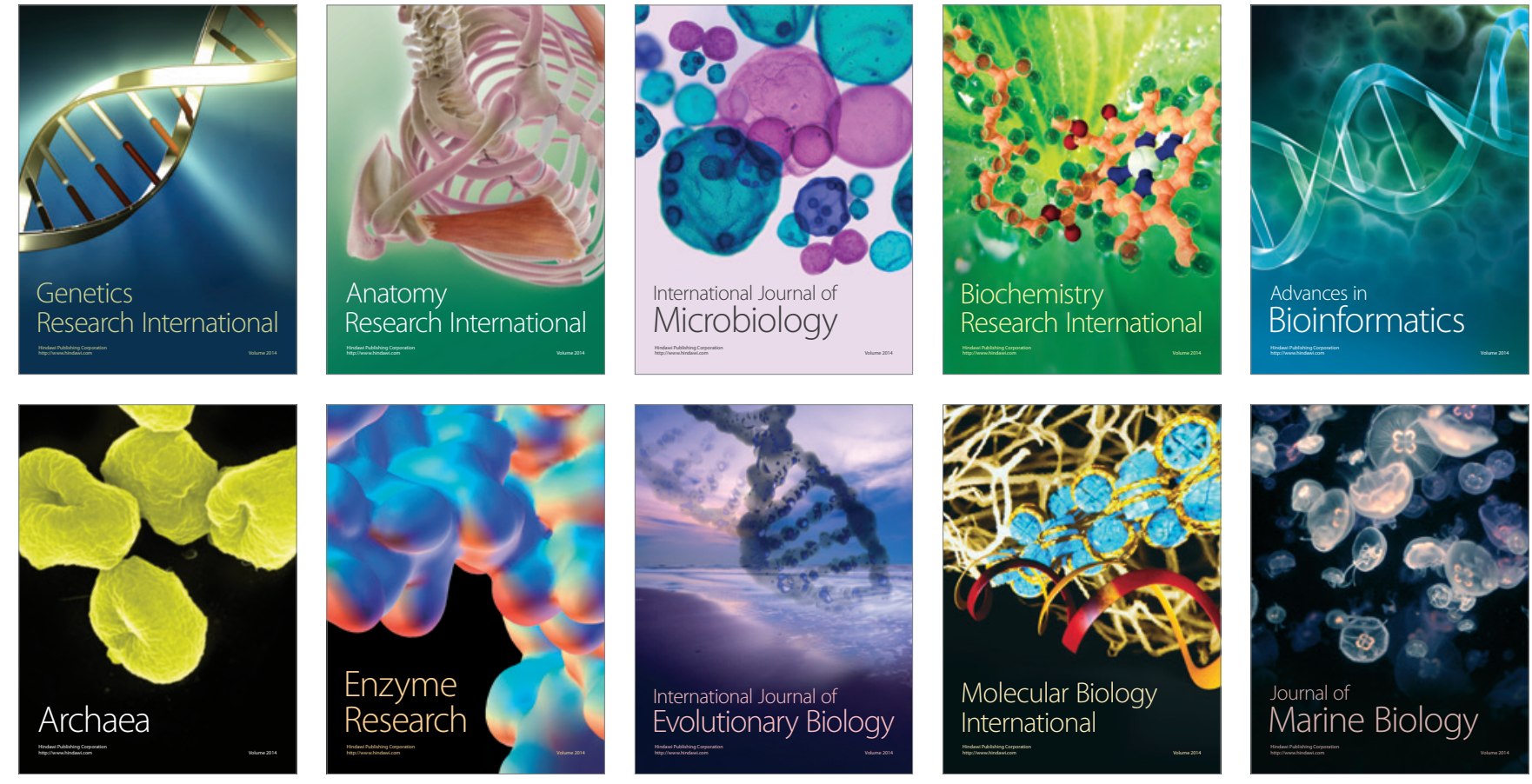